\title{
Deep Connotations of Marx's Theory of Social Interaction from the Contemporary Perspective
}

\author{
XU LI \\ School of Marxism of Wuhan business University \\ Wuhan China \\ 1546687173@qq.com
}

\begin{abstract}
Development of every theory is a progressive, backand-forth long process. Marx's theory of social interaction is no exception. It is established through Marx's development and innovation of previous scholars' theoretical achievements. As an important part of historical materialism, Marx's theory of social interaction is in essence scientific social development theory, which contains rich dialectic ideas. This paper examines the deep connotations Marx's theory of social interaction in terms of the theory's formation process, essence and characteristics. It is hoped that this research can lay a solid foundation for socialist construction using Marx's theory of social interaction.
\end{abstract}

Keywords-Marx; Communication theory; Contemporary background; characteristics

\section{DEVELOPMENT PROCESS OF MARX'S THEORY OF SOCIAL INTERACTION}

Development of Marx's theory of social interaction can be divided into two periods, namely the founding period represented by the publication of Economic and Philosophic Manuscripts of 1844 and the maturity period represented by the publication of German Ideology. In the founding period, Marx mainly inherited the objectivity principle of Hegel and the sociality principle of Feuerbach. Until then, he restored alienation of self-consciousness into alienation of humans and proposed the idea that "the relationship between a person and himself can become the objectivity and realistic relationship via his relationship with others." [1]Therefore, humans' alienation is "actually the relationship between humans and themselves, and it is realized and expressed only through their relationship with others.” [2] Marx summed up the nature of humans into "not an abstract item of individuals but the sum of all social relations on the basis of reality." [3] Here, "the relationship between humans and others" or "social relations" have potentially contained "social interaction", which is a dynamic and practical form of all social relations. In fact, the dynamic and practical form of all social relations can only be realized via social interaction. In this sense, the scope of "social interaction" remains a potential and abstract activity, which has not yet been developed into a practice.

Marx endowed his theory of practice with "social interaction" based on Feuerbach's theory of social relations. Affected by Adam Smith's idea of labor distribution, Marx directly combined social interaction with production, pointing out that "Examination of labor distribution and exchange is an interesting process, because labor distribution and exchange are both external expressions of the human activities and humans' essential power." [4] Marx also held that "labor distribution is a social term of labor in national economics within the scope of alienation.” [5]The book German Ideology writes, "As a terminology, social interaction has a wide range of connotations, which covers both material interaction and spiritual interaction among individuals, social groups and countries. Material interaction is the interaction generated during the production process, which constitutes the basis for any other form of social interaction. 'Verkehrsform' (meaning 'form of social interaction'), 'Verkehrsweise' (meaning 'style of social interaction'), 'Verkehrsverhältnisse’ (meaning ‘social interaction relation') mentioned in German Ideology are concepts of production relations developed by Marx and Engels in their era." [6] "Individuals' social interaction is the prerequisite for production. The form of social interaction is decided by production." [7] As a basic form of activities, production activity can decide the form of social interaction.

In The Communist Manifesto, Marx stated that "the bourgeoisie expanded the world market, turning national production and consumption into a global activity. This is true to production, either materially or spiritually. Spiritual products of different nationalities have become public properties, making enclosed development of nationalities increasingly impossible. As a result, literature of many nationalities and places has opportunities to become world literature." [8] This marks extension of the scope of Marx's social interaction theory to a potential practice rather than limitation to a production relation.

In Capital, Marx regarded social interaction as a tool or means to transform private labor into social labor, saying that "private labor constitutes part of total social labor, and producers are connected via exchange of products." [9] In the opinion of Marx, social interaction is a general social production relation of the commodity society. In other words, "producers take their products as commodities and value, and are connected via the material form by equaling their private labor to human labor." [10] This symbolizes Marx's interpretation of social interaction as a social production relation and a kind of practice.

In The Letter to Bawa Annenko, Marx mentioned the connotation of social interaction while criticizing the historical idealism of Proudhon. "When the form of people's social interaction is unsuitable to the already developed productivity, they will be compelled to change all social forms inherited by 
them to avoid losing achievements and civilizations. Here, I use the word 'commerce' in terms of its broadest sense, which is similar to the word 'verkehr' in German.” [11] This suggests Marx's extension of the meaning of social interaction to its broadest sense, that is, all forms of social and social activities. To sum up, benefiting from extension of the categorical meaning of social interaction, Marx's theory of social interaction has been evolved into a comprehensive and systematic theory.

\section{BASES AND ESSENCE OF MARX'S THEORY OF SOCIAL INTERACTION}

\section{A. Bases for Marx's theory of social interaction}

Any theory cannot be established and developed out of thin air, meaning formation and development of any theory cannot be separated from certain basis and condition. There are also solid bases for formation of Marx's theory of social interaction. These bases can be divided into material ones and economic ones.

\section{1) Material basis}

An important material basis for Marx's theory of social interaction is productivity. In German Ideology, Marx mentioned, "The production starts along with growth of population. The prerequisite for production is social interaction among individuals. The form of social interaction is decided by production.” [12] Though individuals' social interaction constitutes the prerequisite for production activities of material life, the form of social interaction, direct or indirect, material or spiritual is finally decided by production activities.

Apart from production activities, needs and production modes of humans can also decide social interaction. "Therefore, it can be seen that there is a material connection among humans, and the material connection is determined by needs and production modes of humans. Hence, the history of the material connection is as long as the history of humans. Meanwhile, the connection constantly adopts new forms, thus leading to formation of 'history'. It does not need any political and religious visions which seem to gather humans together.” [13] Humans' social interaction is decided by needs and production modes of humans, which almost came into being at the same time when humans appeared. Constant development of social interaction shapes the human history. Therefore, social interaction is also a concept under the category of history.

"The ordinary social interaction among humans is generated only through universal development of productivity. Through extensive interaction, it can be found that masses without 'property' almost exist in every nation (or widespread competition). The reform of one nation and the other nation is interdependent. Finally, regional individuals in the narrow sense are placed by historical individuals which are universal in the real sense.” [14] This means that extensive development of productivity lays a solid foundation for extensive interaction among individuals. Establishment of the universal social interaction promotes formation of the communist society. In other words, social productivity constitutes the fundamental material basis for development of social interaction relations.
Modern industry "creates the world history for the first time, because it makes satisfaction of every person's need in every civilized country rely on the world and eliminates the isolated state among different countries in the past." [15] "Since modern industry ushers in the world history, needs are met via the world history and social interaction derives from satisfaction of needs, modern industry has also contributed partially to formation of social interaction, turning the form of social interaction into a global activity.” Whenever industry and commerce develop to create new forms of social interaction, such as insurance companies, the law has to recognize them as new means to acquire properties." [16] This suggests that modern industry not only gives rise to social interaction, but also creates new forms of social interaction via its development.

\section{2) Economic bases}

Marx expounded on not only material basis of social interaction, but also its economic basis. "Currency turns social interaction and any form of social interaction into something accidental to individuals. Therefore, currency can be defined as the source of the following phenomenon: So far, almost all social interaction is individuals' social interaction under some conditions rather than purely individuals' social interaction. These conditions can be boiled down as the accumulated labor or private system, and the actualized labor. Lack of either can bring an end to social interaction.” [17] Appearance of currency turns social interaction and any form of social interaction into something occidental, highlighting the private system and the actualized labor as a necessary condition for occurrence of social interaction. In other words, currency is a necessary condition for occurrence of social interaction.

"However, supporters of free trade are faced with not only the soaring grain price at times of bumper harvests, but also development crisis of industry and commerce. Meanwhile, the economic crisis mainly happens under the following condition: capitals outflow from California and Australia, adding more complexity to the original world market; the telegram turns the whole Europe into a securities exchange; railways and ships expand the traffic and exchange by more than 100 times." [18] Apart from creating abundant material wealth, free trade has also led to onset of the industrial and commercial crisis, making the world history possible. Moreover, by expanding the range of social interaction relations, free trade has enabled social interaction to develop more rapidly.

"Alliance or revolution is the only way to realize occupation. In the course of revolution, the outdated production and interaction modes are overthrown. Following that, labor is transformed into an autonomous activity. The social interaction people were compelled to have in the past turns into social interaction every person has the right to join or not. In this way, the nature of labor and social interaction is consistent with each other." [19] Impacted by the occupation form of production means, the production activity is either scattered and simple or allied and expanded. On the other hand, social interaction becomes either enclosed or open.

"Nevertheless, the capitalist society based on value exchange nurtures some social interaction and production relations, which are also landmines blowing up the society.” 
[20] The development degree of social exchange is a factor which can most directly decide social interaction relations and wipe out a capitalist society.

\section{B. Essence of Marx's theory of social interaction}

The essence of Marx's theory of social interaction can be examined from the evolution process of the concept of social interaction. Social interaction, emerging first as a production activity, transitions into a production relation and finally evolves into the sum of all social relations and activities. Production activities either related to production relations or related to social relations, all belong to practices. Just as what is written in The Outline of Feuerbach, "Environmental changes are consistent with human activities, which can only be properly regarded as revolutionary practice." [21] "Social activity is in essence a kind of practice." [22] This provides solid support for the essence of Marx's theory of social interaction as a practice. A Chinese scholar Wan also thought, "Marx's concept of social interaction refers to mutual interaction between objects and subjects via certain medium and under some social and historical conditions. The activity is, in the final analysis, a kind of social interaction practice.”

\section{CHARACTERISTICS OF MARX'S THEORY ON SOCIAL INTERACTION}

Marx defined social interaction to be social, practical, medium-based, and subjectivity-oriented.

\section{A. Social}

In The Letter to Bawa Annenko, Marx expanded the scope of social interaction to all forms of social activities and society, defining social interaction as all kinds of activities happening in a society and that society is the basis and foundation of social interaction. Speaking of the civil society, Marx stated, "All forms of social interaction, which are restricted by productivity and restrict productivity, constitute the civil society." [23] Here, "all forms of social interaction" mentioned by Marx is the sum of all social activities and relations. These activities and relations together form the civil society. This helps justify the social attribute of social interaction.

\section{B. Practical}

While proposing individuals as the first prerequisite of all histories, Marx emphasized "the top priority is to avoid reinterpret 'society' as something abstract against individuals. Individuals are existents in the human society.” This means all social life is in essence practical, but all practices must be implemented via labor distribution or cooperation among certain number of individuals connected by social interaction. Thus, social interaction is an indispensable and basic link of human practice, particularly social production. Social development is a time-and-space process which expands social interaction into a social force in history. All in all, social interaction is in essence a kind of practice.

\section{Medium-based}

"Medium-based" means that all social interaction relations among subjects indirectly develop through the medium. It is different from the natural relation among animations, which is established directly without the help of any medium. Production relation is a basic social interaction relation among humans, which has material wealth as its direct medium. It is also the material and interest relation among humans. In other words, the social interaction relation among humans relies on the medium of the relation between humans and nature. This means status of productivity serves as a medium of the social interaction relation among humans. The former restricts the latter, turning the latter into an objective relation. The social interaction relation with the material production activity as the direct medium lays the foundation for all social relations among humans.

\section{Subjectivity-oriented}

Subjectivity is an essential characteristic of interaction. It is reflected as the purpose, consciousness or awareness, and distinguishes social interaction, in which humans are subjects, from the natural relation of animations. The interaction among humans is also conscious and purposeful like the material exchange between humans and nature. This suggests, humans' social interaction happens consciously to some extent. Therefore, humans have social interaction with each other to ensure their material exchange with the nature. If humans are not combined with each other for joint activities and mutual exchange, production will be impossible. Therefore, interaction activities among humans are subject to the status of productivity between humans and nature. Since any productivity is the strength which has already been obtained and is the outcome of the former generation's activities, it is something objective that is already obtained.

\section{CONCLUSION}

Marx's theory of social interaction is in essence scientific social development theory, which contains a variety of development dialectic ideas. From the development dimension, Marx's theory of social interaction, on the one hand, emphasizes production is "the highest standard of social progress". On the other hand, it regards social interaction as important latitude to measure social development and progress. In terms of the development dynamic mechanism, the theory not only recognizes the basic role of material production, but also emphasizes the role of material and spiritual interaction in horizontal and longitudinal evolution. In terms of the development goal, the theory pursues compliance with social development rules as well as purposefulness of social development, and sticks to the unity between the material scale and the human scale. As to the development strategy, Marx's theory of social interaction holds that development of a country "is decided by the development degree of its production and interaction, either within the border or outside the border." This means more attention should be paid to strike a balance between domestic development and opening up. These scientific proposals and ideas play a positive role in socialist construction practice.

\section{REFERENCES}

[1] K. Marx. Economic and Philosophic Manuscripts of 1844[M]. Beijing: People’s Publishing House, 1985: P56.

[2] K. Marx. Economic and Philosophic Manuscripts of 1844[M]. Beijing: People’s Publishing House, 1985: P55. 
[3] K. Marx \& F. Engels. Karl Marx and Frederick Engels: Collected Works[M]. Beijing: People's Publishing House, 1972: P56.

[4] K. Marx. Economic and Philosophic Manuscripts of 1844[M]. Beijing: People's Publishing House, 1985: P105.

[5] K. Marx. Economic and Philosophic Manuscripts of 1844[M]. Beijing: People's Publishing House, 1985: P101.

[6] K. Marx \& F. Engels. Karl Marx and Frederick Engels: Collected Works[M]. Vol. 1. Beijing: People's Publishing House, 1972: P718.

[7] K. Marx \& F. Engels. Karl Marx and Frederick Engels: Collected Works[M]. Vol. 1. Beijing: People's Publishing House, 1972: P25.

[8] K. Marx \& F. Engels. Karl Marx and Frederick Engels: Collected Works[M]. Vol. 1. Beijing: People’s Publishing House, 1972: P254 255.

[9] K. Marx. Capital[M]. Vol. 1. Beijing: People’s Publishing House, 1975: P89.

[10] K. Marx. Capital[M]. Vol. 1. Beijing: People’s Publishing House, 1975: P96.

[11] K. Marx \& F. Engels. Karl Marx and Frederick Engels[M]. Vol. 27. Beijing: People's Publishing House, 1972: P478.

[12] K. Marx \& F. Engels. Karl Marx and Frederick Engels: Collected Works[M]. Vol. 1. Beijing: People's Publishing House, 1972: P25.

[13] K. Marx \& F. Engels. Karl Marx and Frederick Engels: Collected Works[M]. Vol. 1. Beijing: People’s Publishing House, 1972: P34.
[14] K. Marx \& F. Engels. Karl Marx and Frederick Engels: Collected Works[M]. Vol. 1. Beijing: People's Publishing House, 1972: P39 40.

[15] K. Marx \& F. Engels. Karl Marx and Frederick Engels: Collected Works[M]. Vol. 1. Beijing: People’s Publishing House, 1972: P67.

[16] K. Marx \& F. Engels. Karl Marx and Frederick Engels: Collected Works[M]. Vol. 1. Beijing: People’s Publishing House, 1972: P71.

[17] K. Marx \& F. Engels. Karl Marx and Frederick Engels: Collected Works[M]. Vol. 1. Beijing: People's Publishing House, 1972: P73.

[18] K. Marx \& F. Engels. Karl Marx and Frederick Engels[M]. Vol. 10. Beijing: People's Publishing House, 1965: P652 653.

[19] K. Marx \& F. Engels. Karl Marx and Frederick Engels: Collected Works[M]. Vol. 1. Beijing: People's Publishing House, 1972: P75.

[20] K. Marx \& F. Engels. Karl Marx and Frederick Engels [M]. Vol. 46 (Part 1). Beijing: People's Publishing House, 1979: P106.

[21] K. Marx \& F. Engels. Karl Marx and Frederick Engels[M]. Vol. 3. Beijing: People's Publishing House, 1965: P4.

[22] K. Marx \& F. Engels. Karl Marx and Frederick Engels[M]. Vol. 3. Beijing: People's Publishing House, 1965: P5.

[23] K. Marx \& F. Engels. Karl Marx and Frederick Engels: Collected Works [M]. Vol. 1. Beijing: People’s Publishing House, 1972: P41. 